\title{
Regalos de Filipinas a Cádiz en los barcos de la Armada (1765-1784)*/
}

\author{
Gifts from Philippines to Cadiz on \\ the Armada Ships (1765-1784)
}

Alberto Baena Zapatero

ORCID iD: http://orcid.org/0000-0003-4432-259X

Universidad Federal de Goiás (Brasil)

A partir de los registros de entrada de los barcos de la Armada en Cádiz (1765-1784) se analizan los regalos que se enviaban a la Península. Así, se apunta qué mercancías eran preferidas, qué uso se les daba y qué significado tuvieron para sus propietarios. Por último, se recuperan algunas de las relaciones personales tejidas por medio de estas piezas y cuál pudo ser la motivación de las mismas.

Palabras Clave: Filipinas; Cádiz; Comercio; Mercancías; Regalos; Redes.

From the entry records of the Cadiz vessels (1765-1784), we analyse the gifts that were sent to Spain. Thus we will be able to trace the favourite commodities, their usage and their significance to the owners. Lastly, we recover some of the personal relationships that were developed from this dynamics and what could be the motivations behind them.

Keywords: Philippines; Cádiz; Commerce; Commodities; Gifts; Networks.

Copyright: (C) 2017 CSIC. Este es un artículo de acceso abierto distribuido bajo los términos de una licencia de uso y distribución Creative Commons Attribution (CC-by) España 3.0.

* Investigación realizada en el marco del proyecto de investigación «Nueva España: puerta americana al Pacífico asiático (siglos XVI-XVIII)», Programa de Apoyo a Proyectos de Investigación e Innovación Tecnológica (PAPIIT) de la Universidad Nacional Autónoma de México. 


\section{Introducción}

Desde 1765 hasta 1784 un grupo de barcos de la Armada española unió Cádiz y Manila a través del cabo de Buena Esperanza. Se trataba de una novedad, ya que hasta ese momento la ruta tradicionalmente transitada para unir el archipiélago filipino con los puertos peninsulares pasaba por Nueva España y el océano Atlántico. El objetivo que perseguía la Corona con esta reforma era explorar un nuevo camino directo que le permitiera tener un mayor control administrativo y militar sobre Filipinas, pero que al mismo tiempo abriese nuevas oportunidades de negocio a los comerciantes de Cádiz.

En los últimos años los barcos de la Armada han sido estudiados por un pequeño grupo de historiadores, que se han preocupado por diferentes aspectos asociados a los mismos. En primer lugar, Salvador Bernabéu y Antonio García-Abasolo pusieron en valor las importantes contribuciones que consiguieron sus pilotos para la navegación y la ciencia moderna. ${ }^{1} \mathrm{Car}$ los Martínez Shaw y Marina Alfonso, situaron esta reforma dentro de las dinámicas internas del imperio pero también en el contexto político internacional, especialmente como una de las consecuencias derivadas de la guerra de los siete años. ${ }^{2}$ Asimismo, supieron desarrollar la idea apuntada por Lourdes Díaz-Trechuelo en su obra clásica sobre la Compañía de Filipinas, al considerar que este grupo de fragatas y navíos fue el antecedente necesario para la formación de compañías privilegiadas que vinculasen el archipiélago con España. ${ }^{3}$ Desde una perspectiva más novohispana, Carmen Yuste ha destacado lo relevantes que resultaron estos barcos a la hora de proporcionar una alternativa al galeón de Manila y las pérdidas que conllevó para los comerciantes mexicanos la aparición de nuevos actores. ${ }^{4}$ Por último, José Cosano Moyano publicó dos excelentes trabajos sobre las cargas de estos barcos. ${ }^{5}$ No obstante, se trató de un análisis más cuantitativo que enumera las mercancías, siendo todavía necesarios trabajos que se refieran al uso y significado que se dio a una parte de estos objetos, aquellos que no eran destinados al comercio.

1 García-Abásolo, 2000. Bernabéu Albert, 1987; 1992; 2000.

2 Martínez Shaw, 2007. Martínez Shaw y Alfonso Mola, 2013a.

3 Díaz-Trechuelo, 1965, 5-22. Martínez Shaw y Alfonso Mola, 2013b.

4 Yuste, 2007, 360-364.

5 Cosano Moyano, 1981; 1983. 
Durante los quince viajes que realizaron las fragatas y navíos de la Armada entre Filipinas y España, numerosos personajes aprovecharon la ocasión para mandar géneros. Las motivaciones eran frecuentemente económicas, comerciantes de Manila y Cádiz hicieron negocios tanto directamente, al manifestar mercancías en la Real Contaduría, como de forma indirecta, comprando o alquilando el espacio en las bodegas que correspondía a la tripulación de los barcos. A pesar de que la mayoría de los productos embarcados se destinaba al comercio, en los registros de mercancías también se declaraban regalos enviados por vecinos de las islas a alguna persona o institución en España. Asimismo, una pequeña parte de las bodegas de los buques se reservó para el transporte de los equipajes de tripulantes y pasajeros, que también acostumbraban incluir presentes.

El presente artículo se ocupa de analizar estos regalos, organizándolos tanto en función de quién fuese el emisor y el receptor como del objetivo al que se destinaban. A partir de las referencias a los cargadores y consignatarios anotadas en los registros de mercancías, se recuperarán algunas de los vínculos personales que se tejieron con ayuda de estas dádivas. Al mismo tiempo, se procederá a enumerar los principales objetos escogidos para este tipo de uso, reflexionando sobre cuáles eran los más comunes, qué uso se les daba y qué valor pudieron tener para sus propietarios.

Finalmente, con el fin de interpretar el significado que tuvieron los diferentes obsequios identificados, se tomarán en consideración los debates iniciados por la obra clásica de Marcel Mauss sobre la función del intercambio de objetos entre grupos o individuos. Según este autor, los regalos ofrecidos en las culturas antiguas creaban vínculos sociales que obligarían al receptor a corresponder de alguna manera a su emisor («contradon»). ${ }^{6}$ Esta práctica establecía entre ambas partes una «deuda» o «dependencia» que podría entenderse tanto desde el punto de vista material como moral o simbólico. Para poder contextualizar estas remesas en la monarquía española del siglo XVIII resulta necesario también considerar los estudios sobre el funcionamiento del estado moderno, la «cultura del don» y la corrupción. ${ }^{7}$ Además, para aquellos presentes que no estaban directamente asociados a aspectos políticos o económicos, se tendrán en cuenta el ambiente cultural de la época, las obligaciones sociales de los grupos privilegiados, las relaciones de género, o las preocupaciones religiosas.

6 Mauss, 2009, 229-259.

7 Sobre la «cultura del don»: Hespanha, 1993. Cañeque, 2005. En relación al funcionamiento de la monarquía y la corrupción: Pietschmann, 1989; 1998. Van Klaveren, 1989. Vicens Vives, 2000. 


\section{Nuevos intereses científicos y económicos}

Después de la pérdida transitoria de Manila durante la guerra de los siete años contra Inglaterra, se consideró prioritario realizar una serie de reformas que permitiesen mejorar la administración y defensa del archipiélago. Estas preocupaciones se unieron a las reflexiones metropolitanas sobre cómo sacar mayor beneficio de sus territorios ultramarinos. La viabilidad del proyecto dependía de la consolidación de una ruta directa entre España y Filipinas, la cual pondría a prueba los saberes geográficos y náuticos de las nuevas ciencias surgidas en Europa. En primer lugar, era necesario desvelar los secretos de esta travesía, cartografiar los espacios por los que se navegaría, encontrar puntos de avituallamiento y asegurar las derrotas de los barcos. Los encargados de afrontar este desafío serían una generación de pilotos formados en la Compañía de Guardiamarinas conforme a las últimas corrientes europeas introducidas por el militar y científico Jorge Juan y Santacilia. El esfuerzo y los conocimientos de estos marinos permitirían desarrollar métodos modernos de navegación astronómica que abrieron a España la vía a través del cabo de Buena Esperanza. En 1773 Juan de Lángara, al mando de la fragata Venus, aprendió a calcular la longitud naval a partir de las «distancias lunares», contribuyendo a que los oficiales pudieran fijar la posición de sus barcos correctamente. ${ }^{8}$ Gracias a estos logros, como señaló Salvador Bernabéu, las beneficiosas consecuencias de las ciencias colaboraron con el «desarrollo del estado borbónico». ${ }^{9}$ En un momento en que las expediciones marítimas de exploración albergaban también objetivos de toma de posesión de territorios no reclamados por otras potencias europeas, aumento del control administrativo sobre las colonias, y nuevas formas de explotación de los recursos disponibles. ${ }^{10}$

Desde el siglo XVI, los funcionarios destinados en lugares recónditos de la monarquía habían tratado de agradar al monarca enviándole curiosidades, que podían corresponder a piezas producidas por sociedades humanas diferentes o a elementos de la naturaleza descubierta. Así, el historiador Mello Pereira, afirma que «la ciencia moderna se desenvolvió en interacción con la cultura política del Antiguo Régimen, en la cual la dádiva y la reciprocidad tenían pesos determinantes». ${ }^{11}$ En el siglo XVIII, el avance de las

8 Bernabéu Albert, 1987, 449.

9 Idem.

10 De Vos, 2007.

11 Mello Pereira, 2013, 99. 
ciencias y el deseo de clasificación de la naturaleza convivieron con aquellos objetos extraños llegados por la vía tradicional del obsequio al monarca:

Una buena ofrenda, sobre todo cuando es dada a un rey, tenía que ser algo notable y excepcional. La consecuencia es que el coleccionismo de los gabinetes de curiosidades, como el propio nombre dice, tendía a crear un 'microcosmos' caracterizado por la excepcionalidad de las cosas. La gran tarea del siglo XVIII fue pasar de la esfera restricta del ítem excepcional para la noción ampliada de que todo puede ser objeto de colección, clasificación y estudio, pero no debemos perder de vista que la cultura del patronato y de las cadenas de dádivas continuaban muy vivas, cuando no, determinantes en la composición de muchos acervos que se pretendían científicos. ${ }^{12}$

Durante el siglo XVIII, los nuevos intereses científicos llevaron a la creación del Real Gabinete de Historia Natural, la Real Academia de la Historia, o el Real Jardín Botánico. Estas instituciones estimularían la promulgación de instrucciones para la identificación y envío de plantas, animales, minerales y curiosidades. La Real Orden de Felipe V de 1712, la Memoria de 1752 de Antonio Ulloa, la Instrucción de Pedro Franco Dávila de 1776 y la Instrucción de Casimiro Gómez Ortega de 1779, entre otras, organizarían la recolección de piezas en los diferentes territorios de la monarquía. ${ }^{13}$

Ya fuese por iniciativa propia o atendiendo al encargo hecho desde Madrid, los remitentes vieron la oportunidad de llamar la atención del monarca y ganarse una recompensa. ${ }^{14} \mathrm{Si}$ tenemos en cuenta la «cultura del don» imperante en el antiguo régimen, según la cual a cada servicio de un vasallo debía corresponder una merced del rey, se entienden mejor las intenciones de estos funcionarios. ${ }^{15}$ Cada remesa que se enviaba se consideraba como un mérito contraído que debía retribuirse. Este sistema contribuía además al mantenimiento de la lealtad de los súbditos a través del agradecimiento del beneficiado.

En los barcos de la Armada se encuentran numerosos ejemplos de partidas de objetos curiosos o de historia natural para la corte. En 1770, en la fragata Buen Consejo, Francisco de la Concepción y Villanueva, provincial de San Francisco en Filipinas, «atento a la real orden que pedía maderas exquisitas para remitir a Nápoles», despacha de regalo a su majestad una

12 Ibidem, 95.

13 Figueroa, 2012, 122-134.

14 Con este objetivo, en 1746 el gobernador de Filipinas, fray Juan de Erechederra, le había regalado a Felipe V un venado blanco. Según Díaz-Trechuelo y Gómez-Centurión, el interés del religioso sería conseguir el perdón real por haber enviado el galeón a Nueva España, a pesar de ser suspendido por una real orden de 1744. Gómez Centurión, 2009, 186. Díaz-Trechuelo, 2001, 206-207.

15 Cañeque, 2005, 9-11. 
mesa redonda de ébano morado «que los naturales llaman Loyan, un trosso del mismo evano para el pie de dicha mesa, otra dicha de líndalo de nueve palmos y medio de diámetro y más de tres dedos de grueso, un trosso de madera más fina que el tindalo y tan fuerte como el molave vulgarmente llamada colin manuo». Asimismo, afirmaba esperar «más maderas especiales luego que llegue un champan que las conduce de la costa de Tayabas». Todos estos objetos deberían ser entregados al rey por mano de Simón de Anda y Salazar, en ese momento miembro del Consejo de Castilla, quien pudo haber conocido al remitente durante su primera estancia en las islas. ${ }^{16}$

En 1771 sería fray Antonio Mozo, de la orden de San Agustín, el que consignaría a Julián de Arriaga, secretario de Marina e Indias, un presente de objetos de historia natural para el príncipe de Asturias. El heredero al trono se aprovecharía de los mecanismos oficiales de envío de piezas a las instituciones científicas para aumentar su colección privada. Así, la fragata Astrea conduciría «un cajón forrado en lona blanca que contiene varios arbolillos de coral de todos colores, una gran porción de conchas de varias hechuras grandes y colores de nuevas especies de caracoles grandes, medianos y pequeños de hechuras diferentes; petrificaciones de maderas, y mariscos con otras curiosidades $\gg .{ }^{17}$ En este mismo barco y conforme al decreto de 31 de diciembre de 1770 , se pondrían en partida de registro trece cajones, tres de ellos con «conchas y caracoles de mar y los diez restantes de Bonga fruto del país con peso neto de 49 arrobas y 7 libras, todos rotulados al rey Nuestro Señor». ${ }^{18}$

Desde su vuelta al cargo de gobernador en 1770, Simón de Anda y Salazar mantuvo relaciones diplomáticas con los nawabs de la India que le permitirían hacerse con tres elefantes. El primero viajó en 1773 a bordo de la fragata Venus como regalo para Carlos III. ${ }^{19}$ Este presente fue muy bien recibido por el monarca ya que, durante la Edad Moderna, la posesión de animales «exóticos» vivos fue considerada un símbolo de estatus y una manifestación del poder real. ${ }^{20}$ Unos años después, ya con Pedro de Sarrio en el

16 Registro del Buen Consejo, Cádiz, 16 agosto 1770, Archivo General de Indias (AGI), Contratación, 2436, N.2, R.3, 534r-535r.

17 Registro de la Astrea, Cádiz, 1 de agosto de 1771, AGI, Contratación, 2437, N.1, 19v.

18 Ibidem, 55v-56r.

19 El elefante desembarcó en la isla de León, Cádiz, desde donde caminaría 42 días hasta La Granja de San Ildefonso, donde se encontraba Carlos III. Ver: Sánchez Espinosa, 2003. Gómez Centurión, 2009. Mazo, 2008. Este elefante, disecado por Juan Bautista Bru, se conserva en el Museo Nacional de Ciencias Naturales de Madrid.

20 Sobre los animales en la corte española consultar Gómez Centurión, 2009; 2011. 
cargo de gobernador tras la muerte de Simón de Anda en 1776, se volverían a transportar en la Juno «un elefante y tres venaditos vivos» conseguidos por las negociaciones iniciadas por orden del fallecido. ${ }^{21}$ Una vez en Cádiz, el capitán Juan de Araoz sería el responsable de remitirlos al infante Luis, enviándolos con el cirujano por si se morían en el camino a Madrid y era necesario disecarlos. ${ }^{22}$ En esta misma fragata, el oidor Juan Francisco de Anda, sobrino de Simón, envió para el gabinete del infante Gabriel «un saquito de velillo de oro falso, cerrado y sellado con las armas del Ylm. Señor Simón de Anda y Salazar que contiene noventa y siete monedas de oro, plata y cobre». ${ }^{23}$ Probablemente se trató de uno de los regalos póstumos de los que se ocupó Juan Francisco Anda como albacea del gobernador.

En 1779 sería el gobernador ilustrado, José Basco y Vargas, el que despacharía en la Astrea la nada despreciable cifra de 12 cajones llenos de todo tipo de fósiles y animales disecados «destinados al gabinete histórico de $\mathrm{SM}$ ». En la lista de mercancías se alude a los efectos benéficos de algunos de los productos naturales incluidos. Así por ejemplo, se refieren «las piedras de San Xavier aquí llamadas runas que hechas polvo y en agua como masa sirven para deshacer postemas y contra picadura de culebras». ${ }^{24}$

También en la Astrea viajaría Juan Francisco de Anda con otro paquidermo vivo. Como responsable de los bienes dejados por su tío, tuvo que hacerse cargo de una elefanta que el Nabab Hider Alican de Carnate había regalado al mandatario español. ${ }^{25}$ La idea inicial de Simón de Anda había sido que actuase como pareja del ejemplar macho que remitió a España años atrás, pero la falta de colaboración del nuevo gobernador dificultó el traslado. Después de mantenerla durante un año y medio en su casa, Juan Francisco de Anda viajó a Cádiz con el animal. Una vez en su destino y con la ayuda de su primo, Tomás de Anda, encaminaría el animal a Madrid. ${ }^{26}$

Un año más tarde, nuevamente José Basco y Vargas remitió de regalo para el gabinete del rey quince cajones con «curiosidades del país». Además, mandaba otros nueve cajones más con «dos estatuas y dos loros

21 Se trataba de venados enanos de Java. Copia de carta de José Manjón sobre llegada de elefante, Cádiz, 28 de julio de 1778, AGI, Filipinas, 390, N.84.

22 Carta de Juan de Araoz sobre mobiliario y animales para el rey, Cádiz, 17 de julio de 1775 , AGI, Filipinas, 390, N.66.

23 Registro de la Juno, Cádiz, 27 de julio de 1777, AGI, Contratación, 2438, N.1, 16v-17v.

24 Registro de la Astrea, Cádiz, 5 de septiembre de 1979, AGI, Contratación, 2438, N.2, $124 \mathrm{v}-126 \mathrm{r}$.

25 Según el investigador Ángel Goikoetxea (1990), Juan Francisco de Anda despachó en 1777 al Real Gabinete de Historia Natural tres cajones con objetos de fauna marina, conchas y caracoles.

26 Expedientes sobre elefanta para el rey, Madrid, 1778-1780, AGI, Filipinas, 390, N.85. 
encarnados» a José de Gálvez, secretario del Consejo de Estado y ministro del Despacho Universal de Indias, que serían recogidos en Cádiz y reenviados a Madrid por Francisco Manjón, presidente de la Casa de Contratación. ${ }^{27}$ En el último de los barcos de la Armada, la fragata Asunción, el capitán de dragones de Luzón, Juan Mir, obedeciendo los reales decretos dados al efecto, despacharía un cajón con «mancerinas y caracoles de nácar»al Real Gabinete de Historia Natural. ${ }^{28}$ Al mismo tiempo, Juan Antonio del Corral, contador real, «manifestó un cajón que contiene caracoles y muestras de madera que remite para don Isidro Granja», del Consejo de Guerra. ${ }^{29}$

Además de los regalos enviados a la corte, los cargamentos de los buques de la Armada reflejaron las inquietudes culturales de los militares y funcionarios reales de la época, muchos de los cuales fueron los encargados de llevar a cabo los estudios científicos. Así, Juan de Lángara, a la vuelta del viaje al que nos acabamos de referir, llevaba entre su equipaje «un cajón con piezas de historia natural». ${ }^{30}$ Mientras que Alejandro Malaspina, capitán de fragata y segundo comandante, aprovecharía su paso por las islas para incluir en su generala «un surtimiento de bagatelas de historia natural, de encargo», que probablemente le supusieron unos buenos beneficios. ${ }^{31}$

Estas remesas constituyen un ejemplo de cómo las posesiones coloniales fueron aprovechadas desde Europa para ampliar el conocimiento sobre la diversidad natural del planeta. Al mismo tiempo, los regalos despachados también servirían a aquellos que trataban de ganarse el favor real explotando la curiosidad científica del monarca.

Junto a los intereses científicos, los regalos enviados a la Península muestran los propósitos utilitarios e imperiales de la Corona. A lo largo del siglo XVIII fueron redactados numerosos memoriales y proyectos que trataban sobre «el acceso directo desde España al comercio con Filipinas y Extremo Oriente y la transformación del espacio mercantil español del Pacífico». ${ }^{32}$ Los cargamentos estudiados evidencian el deseo reformista real después de la guerra de los siete años y el interés de algunos funcionarios y comerciantes por desarrollar la producción del archipiélago. La mayoría de los géneros embarcados en los barcos de la Armada continuarían siendo

27 Registro de la Juno, Cádiz, 15 de julio de 1780, AGI, Contratación, 2438, N.3, 211v-212v.

28 Registro de la Asunción, Cádiz, 15 de julio de 1784, AGI, Contratación, 2438, N.4, 368r.

29 Ibidem, 366r.

30 Registro de la Venus, Cádiz, 21 de julio de 1773, AGI, Contratación, 2437, N.2, 277r. 353r-353v.

31 Registro de la Asunción, Cádiz, 15 de julio de 1784, AGI, Contratación, 2438, N.4,

32 Martínez Shaw y Alfonso Mola, 2013b, 339. 
REGALOS DE FILIPINAS A CÁDIZ EN LOS BARCOS DE LA ARMADA (1765-1784)

\begin{tabular}{|l|l|l|l|}
\hline \multicolumn{1}{|c|}{ Barco } & \multicolumn{1}{|c|}{ Comandante } & $\begin{array}{c}\text { Llegada } \\
\text { Cádiz }\end{array}$ & \multicolumn{1}{|c|}{ Expediente AGI } \\
\hline Navío Buen Consejo & Juan de Casens & $15-07-1767$ & Contratación, 2436, N.1 \\
\hline $\begin{array}{l}\text { Fragata Santa Rosa } \\
\text { de Lima }\end{array}$ & José de Soroa & $11-08-1770$ & Contratación, 2436, N.2, R.1 \\
\hline Fragata Venus & Manuel González Guiral & $11-08-1770$ & Contratación, 2436, N.2, R.2 \\
\hline Navío Buen Consejo & Juan de Casens & $16-08-1770$ & Contratación, 2436, N.2, R.3 \\
\hline Fragata Astrea & José de Córdoba & $01-08-1771$ & Contratación, 2437, N.1 \\
\hline Fragata Palas & Ignacio de Mendizábal & $17-07-1772$ & Contratación, 2436, N.3 \\
\hline Fragata Venus & Juan de Lángara & $21-07-1773$ & Contratación, 2437, N.2 \\
\hline Fragata Palas & $\begin{array}{l}\text { Gabriel de Alderete } \\
\text { y Morales }\end{array}$ & $16-07-1774$ & Contratación, 2437, N.3 \\
\hline Fragata Juno & Juan de Araoz & $17-07-1775$ & Contratación, 2437, N.4 \\
\hline Fragata Venus & Gabriel de Guerra & $20-07-1776$ & Contratación, 2437, N.5, R.1 \\
\hline Fragata Astrea & Antonio de Albornoz & $20-07-1776$ & Contratación, 2437, N.5, R.2 \\
\hline Fragata Juno & Pablo Vicente Lasaña & $27-07-1777$ & Contratación, 2438, N.1 \\
\hline Fragata Astrea & Antonio Mesias & $05-09-1779$ & Contratación, 2438, N.2 \\
\hline Fragata Juno & Benito Antonio de Lira & $15-07-1780$ & Contratación, 2438, N.3 \\
\hline Fragata Asunción & Juan Ruiz de Apodaca & $15-07-1784$ & Contratación, 2438, N.4 \\
\hline & & & \\
\hline
\end{tabular}

importados, especialmente de China y de la India, pero también comenzaron a incluirse algunos filipinos. Ya no se trataba solo de utilizar el archipiélago como base desde la que acceder al comercio con Cantón, la India y el resto de islas del Pacífico, ahora además se quería fomentar la obtención local de materias primas, generar riqueza y enviarla a la Península. Una parte del azúcar, canela, algodón hilado, palo sibucao y meriñaques que se mandaban eran originarios de las islas y poco a poco se incorporaron los nuevos cultivos implantados de añil, tabaco o cacao. ${ }^{33}$

A pesar de que el mérito del desarrollo de la agricultura y la industria se ha atribuido en gran parte a la inversión posterior de la Compañía de Filipinas, los registros de los barcos de la Armada indican que estos proyectos se venían aplicando desde tiempo atrás. Francisco Leandro de Viana, fiscal de la Audiencia de Manila, escribió en 1765 el memorial «Demostración del mísero y deplorable estado de las Islas Filipinas...», en el que defendía la creación de una compañía comercial que uniera España y Filipinas a

33 Cosano Moyano, 1981, 203. 
través del cabo de Buena Esperanza. Según el autor, este proyecto ayudaría a superar la dependencia filipina de Nueva España y aumentaría los lucros de la metrópoli. Asimismo, proponía el fomento de la producción de las islas y su inserción en el comercio internacional. ${ }^{34}$ Esta preocupación de Viana se manifestaría dos años después, cuando entre las mercancías que remitió de regalo a Francisco de la Guardia, incluiría un envoltorio con «una sobrecama de Ylocos campo blanco y bordado de seda encarnada para que se vea lo que son capaces de hacer los indios de Philipinas». El deseo de llamar la atención sobre el potencial de las islas se refuerza por la presencia en el mismo cajón de petates o esteras hechos por «los indios de Philipinas» $\mathrm{y}$ «vuelos bordados por las indias de Manila». ${ }^{35}$ Francisco de la Guardia era uno de los principales comerciantes de Cádiz y probablemente la intención que tenía Viana al remitir estos presentes era sugerirle las posibilidades de negocio que ofrecía la inversión en la producción filipina. ${ }^{36}$

También en el primer viaje del navío Buen Consejo, Juan Infante de Sotomayor, vecino y del comercio de Manila, embarcó «23 piezas con frutos de la tierra». Entre los productos incluidos en esta categoría se encontraban seis cajas con «un mil setecientas treinta y nueve y media libras de canela de Samboanga» y un cajoncito que iría de regalo para Pedro Calderón Enrique, oidor de Valladolid. ${ }^{37}$ Prueba del desarrollo temprano de cultivos, la explotación de esta especia al sur del archipiélago abría una oportunidad de riqueza que no podía pasar desapercibida ni al rey ni a los comerciantes. No es casual que tanto Viana como Sotomayor, consignasen las mercancías durante el viaje al cuidado de Tomás de Anda y Salazar, que en ese momento regresaba a la corte de Madrid.

Simón de Anda en su informe sobre la situación en Filipinas entregado en 1768 quiso destacar el potencial económico de las islas al sostener que «la especieria se puede poner corriente, que hay oro, añil, bejuco, algodón finísimo, cera, riquísimas maderas, y otros muchos frutos: esto sin tocar en

34 El manuscrito se encuentra en la Biblioteca Nacional de España, MSS/17859, disponible en la Biblioteca Digital Hispánica: http://bdh-rd.bne.es/viewer.vm?id=0000152097\&page=1 (consultado en febrero de 2016). $21 \mathrm{r}-26 \mathrm{r}$

35 Registro del Buen Consejo, Cádiz, 15 de julio de 1767, AGI, Contratación, 2436, N.1,

36 Según sugiere la investigadora Carmen Yuste a partir de la información contenida en las cartas del almacenero mexicano Francisco Ignacio de Yraeta, pudo ser De la Guardia quien puso a disposición de la Corona los primeros barcos que utilizó la Armada a cambio de la autorización de comerciar con las factorías asiáticas. De esta manera, lograría llevar a Manila mercancías de Batavia y Cantón que luego reencaminaría hasta Acapulco por medio del galeón. Yuste, 2007, 360-362.

37 Registro del Buen Consejo, Cádiz, 15 de julio de 1767, AGI, Contratación, 2436, N.1, 30r. 
lo que se puede traer de China y la Costa». ${ }^{38}$ La intención del oficial real era apoyar el proyecto de comercio directo entre España y Filipinas que comenzaría a desarrollarse con los barcos de la Armada.

Los comerciantes residentes en Cádiz estaban vinculados al comercio atlántico y no tenían un buen conocimiento de los mercados asiáticos. Sin embargo, estaban interesados en aprender sobre la oferta de productos que podrían adquirir a través de esta nueva ruta. En el Archivo Histórico Nacional se encuentra una lista, «Géneros y metales de China de nombres no comunes que conducen el Navío Buen Consejo, y las Fragatas Venus, y St. ${ }^{a}$ Rosa», que debió de ser realizada en 1770, año en que estas tres embarcaciones arribaron a Cádiz al mismo tiempo. ${ }^{39} \mathrm{El}$ autor desconocido del documento enumera diferentes productos con sus respectivas explicaciones, por lo que su objetivo debió de ser el de ayudar a aquellos que quisieran invertir en la compra de mercancías asiáticas. En este pequeño catálogo abundan los diferentes tipos de telas y también se hace referencia a las realizadas en Filipinas, aunque en este caso no se les concede un gran valor. De los meriñaques se afirmaba que eran un «tejido de yerbas de nuestras islas equivalente a las telas de zedazo», mientras que de las colgaduras de rengue sostenía que «pueden ser muy especiales por su pintura si es de China, y no de nuestras islas, en donde sólo es ordinario lo que se fabrica». ${ }^{40}$

En 1778, sería el gobernador José Basco y Vargas quien dirigiera al secretario de Estado, José de Gálvez, «quince muestras de géneros bastos de algodón y guimaras indígenas [...] con destino al comercio africano». Probablemente en la mente del gobernador estaba la idea de seguir el ejemplo portugués, que desde el siglo XVI intercambiaba algodón de la India y sedas chinas por oro, marfil y esclavos del África subsahariana. En este caso se introducía una novedad, las manufacturas filipinas, ya que una de las muestras sugeridas era de «lienzo cambaya azul, teñido en Manila». ${ }^{41}$

38 Informe de Simón de Anda y Salazar, Madrid, 1768, AGI, Filipinas, 940. Citado por Cosano Moyano, 1981, 186.

39 Archivo Histórico Nacional de Madrid (AHN), Diversos-Colecciones, 30, N.6. En el mismo archivo se indica a existencia de un documento con la misma filigrana, fechado en Madrid a 20 julio 1779. Se trata de una carta enviada por el ministro José de Gálvez a Francisco Manjón, presidente de la Casa de Contratación, AHN, Diversos-Colecciones, 29, N.5.

40 Géneros y metales de China de nombres no comunes que conducen el navío Buen Consejo y las fragatas Venus y Santa Rosa, s.f., AHN, Diversos-Colecciones, 30, N.6, 1r-1v.

41 Quince muestras de géneros bastos de algodón y guimaras indígenas, remitidos por el gobernador de Filipinas en la fragata Astrea y urca Santa Inés con destino al comercio africano, Manila, 22 de diciembre de 1778, AGI, MP-Tejidos, 34. 
Ya en el último de los viajes de la Armada, el oidor Ciriaco González envió a José de Gálvez un cajón con «muestras de varios tejidos de las Islas» y otro con «café de la misma Isla», evidencias del desarrollo de la agricultura. Pero quizás la prueba más relevante del nuevo impulso tomado por la manufactura local es otro cajón consignado por el mismo funcionario, que contenía «muestras de la primera seda cogida en Filipinas».22 Esta remesa demuestra que, para el momento en que la fragata Asunción partía rumbo a Cádiz, ya se había conseguido introducir con éxito esta producción, abriendo numerosas posibilidades para el comercio y la industria nacionales. Así lo apuntaba el duque de Almodóvar al referirse al algodón, la seda y el añil:

Le ha empezado a promover la Sociedad Económica, y puede hacerle prosperar la compañía. La seda es en Filipinas un nuevo fruto, que por dirección y encargo de la Sociedad en 1780, envió desde China el Padre Galiano religioso Agustino, prevalece prodigiosamente; se hacen nueve cosechas al año, y es susceptible de inmensas ventajas. El añil es otro precioso género que antes era de mala calidad, cultivado con descuido, y casi inservible; pero desde el año de 1779 le promovió eficazmente el padre Octavio, religioso de la misma Orden, quien lleno de espíritu patriótico y de discreto zelo a fueza de un trabajo ímprobo, ha logrado establecer el método de beneficiarle como en Guatimala ayudado de la generosidad y patriotismo de Don Diego García Herreros, inteligente y rico negociante de Manila. Se hizo la primera remesa a Europa en 1784 con la fragata real la Asumpcion, y debe ser este género un considerable objeto de comercio muy digno de una protección bien entendida. ${ }^{43}$

\section{Regalos a la corte}

Los funcionarios destinados en Filipinas no solo mandaron piezas de historia natural a la corte de Madrid, el deseo de agradar al rey también les llevó a enviar objetos «exóticos» o de alto valor que se equiparasen a la categoría del personaje homenajeado. El objetivo pudo ser el mismo, ganarse la voluntad del monarca o agradecerle favores. Como apuntó Francisco Montes para el caso del mecenazgo de los virreyes novohispanos, una de las motivaciones que pudieron tener los oficiales reales de alta graduación para encargar objetos a artesanos locales pudo ser remitir regalos al monarca, a instituciones religiosas o a familiares residentes en España. De esta forma, «las piezas se revestían de valores sentimentales, devocionales e incluso

42 Registro de la Asunción, Cádiz, 15 de julio de 1784, AGI, Contratación, 2438, N.4, 366r.

43 Malo de Luque, 1790, V, 333-334. 
propagandísticos, cuando la idea era contentar al rey mostrándole las maravillas de sus dominios de ultramar». ${ }^{44}$

Las mismas motivaciones que los virreyes tuvieron los gobernadores de Filipinas durante su estancia en las islas. Así, Simón de Anda y Salazar envió al rey a bordo de la fragata Juno catorce cajones que contenían: treinta sillas, un canapé y dos mesas de caña, un tocador, y dos loros de filigrana de plata. ${ }^{45}$ A diferencia de lo que sucedió durante la fiebre evangelizadora de los siglos XVI y XVII, no se incluyeron entre los presentes piezas devocionales hechas por conversos, sino que se trataba en su mayoría de objetos utilitarios que por sus materiales o manufactura llamasen la atención del monarca. En este caso, los muebles de caña fueron adquiridos en Cantón y Simón de Anda destacaría que, aunque por sus materiales podrían parecer cosas pobres, por su trabajo y curiosidad bien podrían complacer al rey. Además, se ofrecía a remitir más objetos de este tipo si eran de su gusto:

Ya se ve que nada de ello es cosa digna de la soberanía, pero por lo extraño de la obra y primoroso trabajo del chino, con solo caña y plata, me ha parecido no dejar de proporcionar la vea y disponga de ella el Rey, [...] son muebles, que de su especie serán acaso los primeros y únicos que se han visto en Europa, y pueden promover alguna nueva idea, de que remitiéndome diseño, me es fácil cumplir cualquier encargo. ${ }^{46}$

Contrariamente a las palabras del gobernador, en el mismo barco varios tripulantes llevaban también piezas de caña: Andrés de Viedma, José Govantes y el propio capitán, Juan de Araoz. Este último, además de incluir entre sus propiedades un cajón con dos canapés de este material, cargaba «2 cajoncitos con 900 abanicos de caña ordinarios» y «1 cajón chico angosto y largo con 800 abanicos de caña ordinarios». ${ }^{47}$ Como se comprueba por el análisis de las mercancías enviadas en los barcos de la Armada, los abanicos realizados en este material fueron una partida numerosa y compartió espacio con los elaborados en maque o marfil. Además, Simón de Anda se encargaría de resolver todos los detalles de su transporte y montaje

44 Montes González, 2009, 507.

45 Nota de lo que contienen los catorce cajones que remite el gobernador de Filipinas para el rey y se han de entregar en Cádiz al marqués del Real Tesoro, Manila, 10 de enero de 1775, AGI, Filipinas, 390, N.60.

46 Carta n. $^{\text {}} 419$ de Simón de Anda y Salazar, gobernador de Filipinas, a Julián de Arriaga incluyendo la nota de canapés, sillas, mesas, un tocador y dos loros de plata que remite para el rey, Manila, 10 de enero de 1775, AGI, Filipinas, 390, N.60.

47 Registro de la Juno, Cádiz, 17 de julio de 1775, AGI, Contratación, 2437, N.4, 587r-587v. 
en Madrid. En primer lugar, se preocupó de que el capitán Juan de Araoz colocase la carga en el barco «con el gran cuidado que pide la delicadeza de la obra de caña y en especial de plata». A continuación explicaba minuciosamente cómo se debería conducir de Cádiz a Madrid:

$1 .^{\mathrm{a}}$ los cajones de n. ${ }^{\mathrm{o}} 1$ a 12 son voluminosos pero de poco peso y pueden conducirse desde Cádiz a la Corte en Galera o carro con alguna cosa blanda por abajo para excusar golpes y debe tener una cubierta que no cale el agua para evitar que ablandada la caña con la humedad se afloje y desfigure la obra.

$2 .^{a}$ Que el número 13 pesa una arroba y el n. ${ }^{\circ} 14$ último mucho menos: por lo que y por la delicadeza de su obra parece forzoso deberse conducir ambos a mano y con el cuidado de que no reciban el menor golpe pues se quiebra fácilmente por más que se ha procurado estivar con papel suave y en los mismos cajones en que vinieron desde el puerto de Cantón: lo más mínimo que padezca la obra creo que no se halle en la corte quien lo componga y aunque no es alhaja que merezca tantas preocupaciones sería sensible que por su omisión se desluciese el primor del trabajo. ${ }^{48}$

Los muebles de caña chinos viajaban desarmados y tenían un complejo sistema de montaje. Para facilitar el acoplamiento posterior se colocaron números en las distintas piezas, pero además, previniendo las dudas de los artesanos españoles, el gobernador mostró en su casa al teniente de fragata Gabriel de Aristizábal cómo se armaban. ${ }^{49}$ La costumbre de transportar los muebles desarmados para protegerlos fue común y se advierte también en algunos ejemplares de laca, si bien en estos casos solía reducirse a separar los pies o peanas del resto del cuerpo. Cuando se trató de biombos el trabajo era más sencillo, ya que sus hojas se colocaban sueltas en los cajones y se acoplaban fácilmente en su destino.

Por otra parte, al igual que se mandaban regalos para el rey también se hizo lo propio con sus ministros, en especial con los miembros del Consejo de Indias. Evidentemente, estos envíos también se hacían con la intención implícita de ganarse el favor político de aquellos que eran responsables de la administración cotidiana del poder. La iniciativa también podía partir del propio funcionario residente en España, quien tratase de aprovechar sus contactos en las islas para encargar alguna pieza de su agrado. Estas mercancías se mandaban solas o entre el equipaje de alguno de los tripulantes o pasajeros de los barcos. Además, podían viajar en nombre de la persona que se desplazaba o de algún residente en Manila que le confiaba esta misión, actuando de esta manera como intermediarios.

48 Carta n. $^{\circ} 419$ de Simón de Anda y Salazar, cit. en nota 46.

49 Idem. 
Muchos de estos regalos estaban hechos con materiales valiosos y delicados, por lo que era habitual que se protegiesen colocándolos en el interior de tibores o entre petates.

Desde el siglo XVI, la posición privilegiada en relación al comercio americano que disfrutaron estos consejeros hizo que en sus ajuares abundasen las importaciones. ${ }^{50}$ En los cargamentos de los barcos de la Armada existen ejemplos de este movimiento de piezas curiosas o de alto valor, predominando entre los receptores el secretario de Marina e Indias y los miembros del Consejo de Indias o de Castilla. Dado el valor de los regalos y que la mayoría de los destinatarios no vivían en Cádiz, se solía encomendar su descarga y posterior envío al presidente de la Casa de Contratación. Como es lógico, desde Filipinas se tenía especial interés en influir en aquellos funcionarios de la metrópoli que tenían relación con la administración de las islas. Si se considera la corrupción como una categoría cultural que «incluye todas aquellas prácticas que aprovechan las contradicciones o ambigüedades del sistema normativo para el lucro personal», los regalos pueden encuadrarse en este tipo de actividades. ${ }^{51}$ En este caso, la corrupción partía de la iniciativa privada y pudo utilizarse como una forma de soborno encubierto.

En 1767 el funcionario Francisco Xavier Salgado envió en el navío el Buen Consejo regalos para el rey y para el secretario de Marina e Indias, Julián de Arriaga, probablemente con la intención de buscar apoyo para sus negocios con la canela y el añil en Filipinas. ${ }^{52}$ En 1770 se registrarían en el mismo barco tres cajones a nombre de Tomás de Mello, secretario del Consejo de Indias, que contenían «una buzeta o tocador de maque con sus cajetas dentro de lo mismo, seis caxitas de Cantón con veinte botecitos de té con dos libras: doscientas y seis piezas y juguetes de losa de China, y quatro esteritas finas, que no consta de partida de registro». ${ }^{53}$ Por sus características es muy probable que este mueble ocupase un lugar especial en los salones del ministro del rey. Además, José Joaquín Martínez, depositario general de Manila, despachó un cajón de regalo a Domingo Trespalacios Escandón, ministro del Consejo de Indias. Entre los objetos remitidos destacaba «una copa de unicornio que se dice contra veneno engastada de plata», sin duda

50 Gil, 2011. Sanz y Dabrio, 1974. Rivas Álvarez, 1986. Aguado de los Reyes, 1994.

51 Lomnitz, 2000, 15.

52 Escoto, 1998, 288.

53 Registro del Buen Consejo, Cádiz, 16 de agosto de 1770, AGI, Contratación, 2436, N.2, R.3, 598r. 
útil para un oficial real con tantas responsabilidades. ${ }^{54}$ Martínez había sido nombrado ese mismo año para el cargo y poco después conseguiría el corregimiento de Tondo, lo que demuestra las excelentes relaciones que mantuvo con la institución de la que formaba parte Trespalacios.

Finalmente, el poderoso José de Gálvez, secretario del Consejo de Estado y ministro del Despacho Universal de Indias, no podía faltar entre el grupo de afortunados que recibieron obsequios. Antonio Pacheco, uno de los comerciantes de Manila más activos en los barcos de la Armada, mandó al ministro «5 cajones con un bajilla de loza fina con escudo de armas de 625 piezas y un juego de cha y café de 143 piezas», además de otros 7 cajones «con piezas y efectos del reino de China». ${ }^{55}$ En este caso, la presencia de las armas de Gálvez en la loza demuestra que se trató de un encargo especial, un símbolo doméstico de estatus que sin duda agradaría a su beneficiario. Dado su valor, el presidente de la Casa de Contratación tomaría todos los cuidados necesarios para hacer llegar la vajilla intacta hasta Madrid.

Cuanto mayor era la posición de poder del funcionario real, más probable era que se recibiese algún regalo. Pedro de Ávila y Soto, Manuel Casafonda, Francisco Manjón o Miguel Orbaneja y Ortega, miembros todos del Consejo de Castilla, recibieron regalos transportados en los barcos de la Armada. ${ }^{56}$ También Simón de Anda y Salazar obtendría varios presentes durante su paso por este Consejo. Justo antes de que el viejo militar partiese nuevamente para las islas como gobernador, José de la Guardia, procurador general de la provincia franciscana de San Gregorio, le hizo llegar dos cajones que contenían «varios ramos de corales, trece petates de varios dibujos y tamaños, seis cocos de pepitas de s Ygn.o y un emboltorio con todo lo necesario para hacer un pabellón tejido de Abaca». ${ }^{57}$ En 1772, sería el turno del conde de Aranda, a la sazón presidente del Consejo de Castilla, quien recibiría un «cajoncito con loza de china que se compone un juego de cha», de parte del arzobispo Basilio Sancho de Santa Justa y Rufina. ${ }^{58}$ Probablemente el religioso buscaba apoyo real en sus conflictos con las órdenes religiosas y el gobierno de las islas.

54 Registro de la Santa Rosa de Lima, Cádiz, 11 de agosto de 1770, AGI, Contratación, 2436, N.2, R.1, 31v-32v.

55 Registro de la Asunción, Cádiz, 15 de julio de 1784, AGI, Contratación, 2438, N.4, 349v.

56 Registro de la Palas, Cádiz, 17 de julio de 1772, AGI, Contratación, 2436, N.3, 704v-705r. Registro de la Astrea, Cádiz, 1 de agosto de 1771, AGI, Contratación, 2437, N.1, 74r-74v y 77r. Registro de la Palas, Cádiz, 16 de julio de 1774, AGI, Contratación, 2437, N.3, 358r.

57 Registro de la Venus, Cádiz, 11 de agosto de 1770, AGI, Contratación, 2436, N.2, R.3, 371v.

58 Registro de la Palas, Cádiz, 17 de julio de 1772, AGI, Contratación, 2436, N.3, 703v-704r. 
La cercanía al monarca también era premiada ya que esta situación proporcionaba influencia sobre sus decisiones. Así por ejemplo, el miembro del Consulado de Manila, Antonio Rivera Montenegro, envió al conde de Baños, grande de España que gozaba de la confianza de la familia real, «un cajón con quince piezas de loza de China». ${ }^{59}$ En algunos casos la estrategia pudo haber sido ganarse el favor de un familiar del funcionario con el que se deseaba tener buenas relaciones. De esta forma, el gobernador José de Basco y Vargas, entregaría a la mujer del presidente de la Casa de Contratación, María Teresa Micón y Manjon, «un cajón con doce laminitas con sus cristales». ${ }^{60}$ También la condesa de Tepa, una vez que su marido formaba parte del Consejo de Indias, recibiría un colmillo adornado de oro y plata del importante comerciante filipino, Pedro Galarraga. ${ }^{61}$

A pesar de que Horst Pietschmann, acompañando las reflexiones de Van Klaveren, sostiene que «la corrupción en América ha tenido un carácter de sistema y habrá que explicarla en términos de una tensión más o menos permanente entre el Estado español, la burocracia colonial y la sociedad colonial», los regalos demuestran una relación de intereses entre los funcionarios de la Península y una parte de la élite económica de Manila. ${ }^{62}$

\section{Regalos entre particulares}

El siguiente tipo de regalos es aquel que un individuo remitía a otro particular o institución. Como ya explicamos, el don fue utilizado para crear relaciones de gratitud y correspondencia entre personas o grupos, práctica común al conjunto de la sociedad y no se limitó a la esfera política. Partiendo desde la investigación del derecho, Antonio Manuel Hespanha explicó la formación de «redes sociales» en función del sistema de intercambio material y simbólico que caracterizó el Antiguo Régimen y de conceptos como la amistad o el amor. Así, estas redes son consideradas:

A la hora de describir el modo en virtud del cual los agentes distribuyen recursos socialmente escasos (recursos económicos, empleos, honores y distinciones sociales, saber e información). Cada red puede ser considerada como un circuito social

59 Registro de la Santa Rosa de Lima, Cádiz, 11 de agosto de 1770, AGI, Contratación, 2436, N.2, R.1, 40r-40v.

60 Registro de la Juno, Cádiz, 15 de julio de 1780, AGI, Contratación, 2438, N.3, 212v.

61 Registro de la Asunción, Cádiz, 15 de julio de 1784, AGI, Contratación, 2438, N.4, 352v.

62 Pietschmann, 1998, 182. 
en el que se llevan a cabo intercambios (exchanges, transactions) de servicios, tanto actuales como virtuales. Si los intercambios son desiguales (o asimétricos), la parte acreedora gana en ascendencia, dando entonces origen a una relación de poder. Esta situación de desequilibrio se expresa con mucha frecuencia a través de la idea de «amistad» — respecto del acreedor: significa buena disposición para hacer un favor sin exigencia expresa de devolución - y de «respeto», «solicitud» o «consideración» - respecto del deudor: significa buena disposición para hacer servicios futuros e indeterminados. ${ }^{63}$

Entre los vecinos de Filipinas fue habitual la creación de redes a la larga distancia mediante el envío de presentes a algún comerciante en la Península. Siguiendo la pista de estos regalos podemos recuperar los vínculos personales o comerciales que hubo entre numerosos personajes de España y Filipinas, y el deseo, por lo menos de una de las partes, de agradar al otro, suponemos que con algún tipo de intencionalidad práctica. Entre estas relaciones, como vimos, estuvo la que mantuvieron Francisco Leandro de Viana, uno de los principales defensores de la apertura de la ruta del cabo de Buena Esperanza, y Francisco de la Guardia, marques de los Castillejos, comerciante afincado en Cádiz que con su enorme inversión ayudó a financiar el proyecto. ${ }^{64}$ En 1767 Viana mandó un cajón de regalo a De la Guardia, seis años después este tendría la oportunidad de demostrar su agradecimiento y amistad invitándole públicamente a suscribirse a la Real Sociedad Bascongada de Amigos del País. ${ }^{65}$ En ese momento Viana había sido promovido a oidor de la Audiencia de México y desde este cargo continuaría velando por los intereses de Francisco de la Guardia en Nueva España, hasta que en 1776 volviera a la Península. El regalo enviado en el Buen Consejo demuestra que el vínculo entre estos dos personajes era anterior a la labor desempeñada por el futuro conde de Tepa en la Real Sociedad.

Diecisiete años después de que Viana mandase aquel presente a De la Guardia, para el sacerdote José de Jesus Días Vardera seguía estando clara su relación. Entre los objetos que manifestaría para embarcar en la fragata Asunción registró «un cajon lleno de conchas y caracolitos» para el antiguo fiscal y «un cajoncito con azucar de piedra» para el comerciante. ${ }^{66}$ Además, el hecho de que Francisco Leandro de Viana consignara las mercancías al

\footnotetext{
63 Hespanha, 1993, 156.

64 Registro del Buen Consejo, Cádiz, 15 de julio de 1767, AGI, Contratación, 2436, N.1, $21 \mathrm{r}-26 \mathrm{r}$.

65 Torales Pacheco, 2001, 69-70. $351 \mathrm{r}-351 \mathrm{v}$

66 Registro de la Asunción, Cádiz, 15 de julio de 1784, AGI, Contratación, 2438, N.4,
} 
cuidado de Tomás de Anda y Salazar, anticipa las excelentes relaciones que tendrá con el posterior gobernador de las islas, Simón de Anda.

Son precisamente Francisco de la Guardia y Tomás de Anda los protagonistas de otro triangulo de relaciones que es posible recuperar gracias a los registros de entrada de los barcos de la Armada. Juan Francisco Solano, comerciante de Manila, en 1767 enviaría al cuidado de Tomás de Anda dos cajones de regalo con loza de China, piezas de Chitas, pañuelos encarnados, petates y algunas objetos de plata, que Francisco de la Guardia debería recoger al llegar a puerto. ${ }^{67}$ En los años posteriores, Solano despacharía grandes cantidades de productos al comerciante afincado en Cádiz. En la Palas, por ejemplo, compraría las generalas del teniente de navío y segundo comandante Gabriel Alderete, del contador y maestre de fragata Juan José de Avendaño, del primer piloto José Nolante, y del pilotín José Ortega, para enviar mercancías a Francisco de la Guardia. ${ }^{68}$ Mientras que en 1776, en el registro de la fragata Astrea, el piloto Domingo Manuel de Paz manifestaría 12 generalas por un valor de 12567 pesos, que irían de cuenta y riesgo de Solano y consignadas al marqués de Castillejo. ${ }^{69}$

Los lazos entre estos personajes se entienden mejor al estudiar las cartas que Francisco de la Guardia escribió entre 1772 y 1773 a Tomás de Anda, en ese momento residente en Madrid. Bartolomé Solano, hijo de Juan Francisco Solano, había viajado a España, quedando bajo la tutela de Anda e Ignacio Balzola. El marqués, por su parte, se ocupaba de servir de intermediario con el padre y de sufragar los gastos de la educación del joven a través de sus agentes financieros, los hermanos Romero de Tejada. Durante su estancia, pagaría sus estudios en el colegio de nobles y un nombramiento en la compañía de infantería del regimiento del príncipe, además de remitirle los cajones que mandaba su padre. ${ }^{70}$ Así, los regalos enviados por Solano pudieron haber sido una forma de pago por los favores recibidos o una manera de mandar mercancías a su hijo.

Francisco de la Guardia y Francisco Leandro de Viana formaron parte de otra red de conexiones, en este caso con el comerciante de Manila, Pedro de Asteguieta. Dentro del cajón de regalo que envía Viana a Francisco de la $9 \mathrm{v}-11 \mathrm{v}$.

67 Registro del Buen Consejo, Cádiz, 15 de julio de 1767, AGI, Contratación, 2436, N.1,

68 Registro de la Palas, Cádiz, 17 de julio de 1772, AGI, Contratación, 2436, N.3, 679v-680r, $685 \mathrm{v}-686 \mathrm{r}, 688 \mathrm{v}$ y $691 \mathrm{r}$.

69 Registro de la Astrea, Cádiz, 20 de julio de 1776, AGI, Contratación, 2437, N.5, R.2, 728v.

70 Juan Francisco Solano mandó una caja con juguetes chinos para su hijo. Newberry Library, Special Collections, Chicago. VAULT box Ayer MS 1925, MS 1994, MS 1996. 
Guardia se encontraba un envoltorio y una caja que Pedro de Asteguieta dirigía a su hermano Domingo, administrador principal de la renta del tabaco de Murcia. Entre los objetos remitidos se encontraban diversas telas, cuatrocientas piedras de culebra y numerosas piezas de tumbaga. ${ }^{71}$ En 1772 , Asteguieta ingresó en la Real Sociedad Bascongada de Amigos del País y, como comisionado en Manila, mandó mercancías a De la Guardia en los barcos de la Armada hasta su muerte en 1775. Por tanto, los tres fueron de origen vasco y los tres acabarían perteneciendo a La Bascongada.

Francisco de la Guardia también mantendría una colaboración estrecha con Juan Agustín de Uztáriz, marqués de Echandía, miembro de una importante familia de comerciantes navarros afincados en el puerto gaditano. Uztáriz compró generalas de los barcos de la Armada y acostumbraba a aparecer como segundo consignatario en todas aquellas partidas destinadas a De la Guardia. Asimismo, entre las mercancías manifestadas por Juan de Araos, comandante de la fragata Juno, que iban de cuenta y riesgo de Pedro Sisto y del marqués de Echandía, se hallaba un envoltorio rotulado al marqués de Castillejos con seis piezas de cambray de la costa. ${ }^{72} \mathrm{~A}$ su vez, los comerciantes Sisto y Uztáriz, junto al canónigo Domingo de Villanueva, serían los encargados de recibir los presentes que Simón de Anda enviaba a su hijo, vecino de Madrid. Posteriormente, también sería Pedro Sisto quien se ocuparía en Cádiz de las partidas enviadas por el oidor Juan Francisco de Anda a su primo Tomás. La ayuda prestada es la prueba de la relación próxima y de confianza que existió entre el gobernador y el comerciante.

Anda no fue el único funcionario con el que el marqués de Echandía sostuvo buenas relaciones, en 1772 recogería un cajón de loza china de regalo del tesorero y oficial real de las Cajas de la ciudad de Manila, José Antonio de Larzábal. ${ }^{73}$ Asimismo, su primo, Juan Bautista de Uztáriz, conde de Reparaz, también recibiría del comerciante de Manila, Pedro de Galarraga, una vajilla de porcelana, un baúl de palo de rosa lleno de géneros y un biombo de 24 hojas. ${ }^{74}$ Todo lo cual demuestra el interés por los géneros asiáticos que tuvieron los miembros de esta familia, ya desde antes de que

71 Las piedras de culebra eran indicadas para quitar el dolor de cabeza. Registro del Buen Consejo, Cádiz, 15 de julio de 1767, AGI, Contratación, 2436, N.1, 26v-27r.

72 Registro de la Juno, Cádiz, 17 de julio de 1775, AGI, Contratación, 2437, N.4, 473v-474v.

73 Registro de la Palas, Cádiz, 17 de julio de 1772, AGI, Contratación, 2436, N.3, 705v-706r.

74 Registro de la Astrea, Cádiz, 1 de agosto de 1771, AGI, Contratación, 2437, N.1, 72r-73v Pedro de Galarraga, marqués de Villamediana y administrador de la renta del tabaco en Manila, mandaría años después un conjunto de plata labrada y ornamentos para la catedral de Tudela. Heredia Moreno, 2008, 350. 
se formara la compañía «Uztáriz y San Ginés» para el trato con Filipinas. Si se tiene en cuenta su participación económica en los cargamentos de la Armada y sus relaciones con comerciantes y funcionarios de las islas, se entiende mejor cómo fue estableciendo las bases para desarrollar su posterior proyecto de comercio directo. A partir de 1779 Juan Agustín de Uztáriz constituiría junto a Francisco de Llano San Ginés la primera compañía comercial para el trato entre Cádiz y Filipinas. ${ }^{75}$

Una nueva ruta necesitaba tejer nuevas redes comerciales y estos regalos sirvieron como instrumento para afianzarlas. De esta manera, otra asociación interesante es la que se dio entre Enrique de Olavide y Michelena, quien fuera gobernador de las Marianas (1749-1756) y que en ese momento se dedicaba al trato en Manila, y el comerciante Matías de Landáburu, quien tenía importantes negocios en varios puertos de América. ${ }^{76} \mathrm{El}$ primero remitió de regalo a Cádiz cuatro tibores de loza de China pintados «con sus leones en las tapaderas abrigados con manta y cavo negro» y en un baúl un envoltorio con chitas. Dentro de dos de los tibores iban además diez petates de diferentes tamaños que eran también para Landáburu y un envoltorio con telas, un petate y cuatro cajoncitos de té para José Taboada, oficial del ramillete del rey. ${ }^{77}$

Tanto Francisco de la Guardia como Matías Landáburu formaron parte de un grupo de negociantes de origen vasconavarro residentes en Cádiz y enriquecidos por el comercio colonial, que aspiraban a un título nobiliario. ${ }^{78}$ Para ambos, sus deseos de reconocimiento social debían apoyarse en un estilo de vida aristocrático para el que contribuirían excelentemente los obsequios que acababan de recibir. ${ }^{79}$ Ninguno de los dos debió esperar mucho para ver hechas realidad sus ambiciones, en 1769 Francisco de la Guardia se convertía en marqués de los Castillejos, mientras que en 1772 Landáburu compraría al conde de Aranda el vizcondado de Biota. A sus respectivos donantes también les iría muy bien, Leandro de Viana acabaría siendo nombrado conde de Tepa y promovido al Consejo de Indias,

75 Para más información: Herrero Gil, 2008-2009.

76 Enrique de Olavide y Michelena aparece en la nómina de comerciantes del Consulado de Manila de 1771. Yuste, 2007. Sobre Matías de Landáburu y la familia Uztáriz: Martínez del Cerro, 2006.

77 Registro del Buen Consejo, Cádiz, 15 de julio de 1767, AGI, Contratación, 2436, N.1, 3v-4r.

78 Véase Anes Fernández, 2001.

79 Ignacio de Balzola y Larreche, segundo capitán de fragata Santa Rosa de Lima, transportó regalos suntuosos tanto para Francisco de la Guardia como para Matías de Landáburu. Registro de la Santa Rosa de Lima, Cádiz, 11 de agosto de 1770, AGI, Contratación, 2436, N.2, R.1, 33v-34r y 256r. 
mientras que Enrique de Olavide y Michelena volvería a ocupar el cargo de gobernador de las Marianas.

Otra red que no podría dejar de reflejarse en los cargamentos de la Armada es la protagonizada por la importante familia de comerciantes encabezada por José Antonio de Memije y Quiroz, alguacil mayor de Manila. $\mathrm{Su}$ sucesor en el cargo, Vicente Laureano de Memije, despachó cuatro cajas de regalo, una rotulada a Carlos Valenciano, contador mayor y juez oficial del Tribunal de la Casa de Contratación, y tres a Manuel de Memije, comerciante afincado en Cádiz. ${ }^{80}$ Vicente Laureano aprovechó los barcos de la Armada para comprar generalas y enviar mercancías a Manuel de Memije y José Savater, por lo que unas buenas relaciones con la Casa de Contratación siempre serían ventajosas para los negocios. Al mismo tiempo, Joaquín Fabián de Memije, miembro de la familia desplazado a México, actuaba como apoderado de los intereses del gobernador José Antonio Raón en Nueva España. ${ }^{81}$ Dado su trato con la familia de mercaderes, se entiende mejor el hecho de que cuando el oficial real quiso mandar regalos a su mujer, Teresa Zejudo, residente en la Rioja, pidiese que se entregasen en Cádiz a Manuel de Memije, quien los haría llegar a su destino. ${ }^{82}$

También es posible descubrir relaciones entre militares de una misma familia. Los hermanos Sebastián y Juan José Ruiz de Apodaca, formarían parte de las tripulaciones de los barcos de la Armada y después harían carrera dentro del ejército. Antonio Apodaca, quien fuera gobernador de las Marianas, mandaría tres cajones de regalo a Francisco Wentuisen, jefe de escuadra de la Real Armada, registrando a Sebastián y a su madre, Eusebia María de Eliza, en segundo y tercer lugar. ${ }^{83}$

En muchas ocasiones lo que se buscaba era despachar objetos excepcionales que llamaran la atención de su receptor en España. El comerciante Gregorio del Escobal afirmó enviar para obsequio que debía hacer en la corte de Madrid, dos tibores y un cajón con «menudencias». La lista de piezas incluidas demuestra en muchos casos un interés por lo original o «exótico». Así, se registran dos figuras de metal de China con cabeza y manos de marfil, diez figuritas de loza, una cajita de nácar con tres piezas de paños de paliacate para narices, rollos de papel con figuras de China, un palillero

80 Registro del Buen Consejo, Cádiz, 16 de agosto de 1770, Ibidem, R.3, 537r-537v.

81 Yuste, 2007, 115-119.

82 Registro del Buen Consejo, Cádiz, 15 de julio de 1767, AGI, Contratación, 2436, N.1, 17r-18r. Registro de la Santa Rosa de Lima, Cádiz, 11 de agosto de 1770, Ibidem, R.1, 7v-10v.

83 Juan José Ruiz de Apodaca llegaría a ser virrey de la Nueva España. Registro de la Juno, Cádiz, 27 de julio de 1777, AGI, Contratación, 2438, N.1, 14r. 
de diente de caimán en una cajita de marfil y esmalte, un par de leones de loza, y un caracol de madre perla, entre otros objetos. ${ }^{84}$ La misma intención pudo tener Francisco Enríquez, comerciante de Manila, que en 1780 envió a su colega en Cádiz, Roaf Aguado: «Catorce piezas de figuras de raíces de árbol» $\mathrm{y}$ «una silla grande de caña de Cantón poltrona». ${ }^{85} \mathrm{El}$ hecho de que estas mercancías vinieran junto a otros muchos objetos de maque de Cantón, nos lleva a pensar que Enríquez tuvo un acceso privilegiado al trato con este enclave comercial, principal puerta de salida de los productos chinos.

\section{Regalos y limosnas}

Existió otro tipo de regalos, aquellos que se hacían a instituciones religiosas y que en las fuentes de la época se denominaban «limosnas». Durante el periodo colonial fue frecuente que religiosos y laicos desplazados a Filipinas o América enriquecieran las iglesias de sus lugares de origen con ofrendas de piezas litúrgicas realizadas por artesanos locales. La intención del remitente de estas donaciones pudo ser la de mostrar públicamente la fortuna conseguida o la de agradecer a la devoción local la protección recibida. ${ }^{86}$ Este fue el caso de Enrique de Olavide y Michelena, quien dirigió por medio de Matías de Landáburu una donación al monasterio y seminario de San Salvador de Urdax, en el valle navarro de Baztán, de donde era originario su linaje. Se trataba de «un baúl de maque encarnado y oro con su escudo en la tapadera, contiene un ornamento pontifical bordado de oro, plata, y seda sobre razo liso blanco doble, con su escudo, forradas todas las piezas en pequín grana». ${ }^{87}$ La heráldica impresa en el baúl y en el ornamento indica la voluntad del remitente de dejar testimonio de su donación. La decoración personalizada y la técnica utilizada tanto en el baúl como en los «dos atriles de maque encarnado con oro» y las «seis sillas grandes de altar de maque encarnado con oro», sugieren que esta obra pudo ser un encargo directo a un artesano asiático, al que se le facilitaría un modelo de la imagen que debería reproducir. ${ }^{88} \mathrm{Si}$ se tiene en cuenta que muchos de los trabajos

\footnotetext{
84 Registro del Buen Consejo, Cádiz, 15 de julio de 1767, AGI, Contratación, 2436, N.1, $52 \mathrm{r}-54 \mathrm{v}$.

85 Registro de la Juno, Cádiz, 15 de julio de 1780, AGI, Contratación, 2438, N.3, 196r-196v y 317 r.

86 Montes González, 2009, 507.

87 Registro del Buen Consejo, Cádiz, 15 de julio de 1767, AGI, Contratación, 2436, N.1, 4r-5v.

88 Ibidem, $4 \mathrm{r}-4 \mathrm{v}$.
} 
chinos de exportación se caracterizaban también por fondos rojos y figuras doradas, podemos suponer que el autor pudo ser de este origen. Lo que resulta imposible de determinar es si se realizaría en Manila o si lo haría en algún taller del continente, probablemente cerca de Cantón, ya que desde el siglo XVI hubo una población permanente de sangleyes en la ciudad que se ocupó de suministrar manufacturas al galeón.

El arzobispo de Manila, Basilio Sancho de Santa Justa y Rufina, no se olvidó ni de su tierra natal en Teruel ni de su pasado por Zaragoza. Entre los regalos y limosnas que envía por medio del padre Joaquín de Santo Domingo se encontraban «un cáliz con su patena de oro consagrado» para las escuelas pías de Zaragoza, de las que fuera secretario general al inicio de su carrera eclesiástica. A esta misma ciudad remitía «dos bastones con puño de oro», sin duda excelentes símbolos de jerarquía y estatus para José y Domingo Tragia, teniente coronel y capitán del regimiento de voluntarios a caballo de Aragón. Finalmente, se acordaba de la iglesia del pueblo en el que naciera, Villanueva del Rebollar de la Sierra, adonde mandaba «tres cavillas» de limosna. ${ }^{89}$

También algunas monjas españolas tuvieron la suerte de recibir géneros de regalo desde Filipinas. La madre María de los Dolores, religiosa carmelita descalza en Málaga, disfrutaría de un cajoncito con telas pintadas, dos sombreros de marfil, diferentes tipos de loza y un petate pintado, que le enviaría Baltazar de Cozar en la fragata Venus. ${ }^{90}$ También Juan Álvarez Valcárcel, fiscal de lo civil de la Audiencia de Filipinas, aprovechó la intermediación del comerciante afincado en Cádiz, Esteban de Acuña, para enviar regalos y limosnas a religiosas. A las monjas de Medina Sidonia les hizo llegar «un emboltorio con dos petates con oropel de la Laguna», mientras que a su hijo, José Javier Gálvez, «un bastón de puño de oro». ${ }^{91}$

En ocasiones no fueron residentes en las islas los que enviaron objetos a iglesias o religiosos de la Península, sino justamente al contrario. Fray José de San Buenaventura, procurador general de los agustinos descalzos de la ciudad de Manila, remitió en nombre de su provincia numerosos géneros al duque de Híjar. Este envío se explica porque Pedro de Alcántara Fernández de Híjar, tenía el título de patrono y protector general de la Sagrada Congregación de Recoletos Agustinos Descalzos de España,

89 Entre los regalos también iría una casulla para fray Jorge Rey, de la orden de San Agustín, residente en Barcelona. Registro de la Palas, Cádiz, 17 de julio de 1772, AGI, Contratación, 2436, N.3, $703 \mathrm{v}-704 \mathrm{r}$.

90 Registro de la Venus, Cádiz, 11 de agosto de 1770, AGI, Contratación, 2436, N.2, R.2, 371r.

91 Registro de la Juno, Cádiz, 15 de julio de 1780, AGI, Contratación, 2438, N.3, 200v-202r. 
Indias y Filipinas. Entre las mercancías expedidas estaban un baulito de concha y plata que tenía tres piedras basares de venado adornadas de oro, una sobrecama de algodón bordada, dos cajoncitos de té, dos colmillos de caimán y 500 piedras de culebra. ${ }^{92}$ En este como en otros casos, no es fácil saber si se trató de un regalo hecho por iniciativa de los religiosos de Filipinas o si el duque aprovechó su posición para encargarles piezas asiáticas, entre ellas algunas con supuestos efectos medicinales.

Francisco López Perea, maestrescuela de la catedral de Manila, mandó objetos tanto a religiosos como a comerciantes. En 1773 despachó dos cajones al dominico fray Sebastián Valverde, procurador general de la provincia del Santísimo Rosario de Filipinas en la corte de Madrid. ${ }^{93}$ Tres años después, remitiría al comerciante Simón Babil de Uris «un San Sebastián de marfil de dos quartas y media de largo, en su árbol de lo mismo». ${ }^{94}$

\section{Regalos a familiares}

Otra situación muy habitual en los barcos de la Armada fue el envío de regalos a un familiar por parte de algún personaje importante de Manila, normalmente funcionarios de alta graduación destinados en las islas. Ya en las normas para el comercio entre Filipinas y Nueva España se había previsto esta situación, al establecer en uno de sus artículos «que se permita a los Gobernadores, ministros togados y a los oficiales reales de Manila puedan enviar a sus correspondientes en estos reinos algunos cajones con regalos». ${ }^{95}$ Para muchos de estos personajes, el paso por América o Filipinas era una oportunidad para enriquecerse y adquirir piezas de lujo a un precio menor que en España. Así, estas cargas podían destinarse a mejorar los ajuares domésticos de sus lugares de origen, incluyendo ricas y prestigiosas piezas orientales. Además, estos objetos solían colocarse en el salón principal de la casa y servirían para recordar a las visitas la experiencia cosmopolita de su dueño. Este pudo ser el caso del gobernador José Raón, que remitió en el navío Buen Consejo y en la fragata Santa Rosa de Lima varios presentes para su mujer e hijos. Entre estos se contaron una escribanía y varias piezas

92 Registro de la Astrea, Cádiz, 1 de agosto de 1771, AGI, Contratación, 2437, N.1, 75v-76r.

93 Registro de la Venus, Cádiz, 21 de julio de 1773, AGI, Contratación, 2437, N.2, 220v-221r.

94 Registro de la Venus, Cádiz, 20 de julio de 1776, AGI, Contratación, 2437, N.5, R.1, $653 \mathrm{r}-653 \mathrm{v}$.

95 Normas para el comercio entre Filipinas y Nueva España, 15 de septiembre de 1726, AGI, Filipinas, 342, L.9, 223r-228r. 
de plata, papeleras con ropa y alhajas, dos bastones, un retrato, tres cajas de maque, tibores y una gran variedad de porcelana, doce abanicos de nácar y marfil con varias figuras de china, un tocador de maque, un vaso de cuerno de ciervo, petates, un San José con su cristal dorado, y hasta tres estampas de Palafox. ${ }^{96}$ Finalmente, a su vuelta a España en 1773, transportaría en su equipaje «una papelera con cuatro abanicos para sus hermanas». ${ }^{97}$

Sobre este asunto, merece especial atención el gobernador Simón de Anda y Salazar, ya que durante los años en los que estuvo en el cargo envió a su hijo numerosas partidas de regalos. Entre 1772 y 1776, las fragatas Palas, Venus, Juno y Astrea transportaron inmensas riquezas remitidas a Tomás de Anda y Salazar. La lista de objetos de lujo que se incluyeron en estos presentes es muy extensa y tan solo se referirán los más significativos. Las remesas comenzaron al poco tiempo de asumir el cargo, la Palas llegaría a Cádiz cargada con regalos del gobernador para su hijo y varios comerciantes de la ciudad, Gregorio Alzasua, Esteban de Acuña y Pedro de Anda. Entre los objetos que obtuviera Tomás de Anda destacaban una papelera, diez y seis figuras de sangleyes, y dos uniformes azules bordados de oro. ${ }^{98}$

Un año después sería el turno para la fragata Venus. El gobernador utilizaría la generala del contador José García Armenteros para enviar libres de impuestos numerosas piezas de filigrana, un biombo chino, porcelana, abanicos, etc. Entre la ropa llamaban la atención «4 bestidos de chinos y 4 de chinas» que, en una nota al margen, se sugiere que pudo tratarse de disfraces con todos sus complementos: «se componen de ocho camisas, ocho calzones, cento cuarente y cuatro botones, quatro collares, quatro monteras, quatro ceñidores con bolsas, quatro abanicos, quatro pares de zapatos, quatro de botas, y ocho mascaras». ${ }^{99}$ En la lista de nombres de géneros del Archivo Histórico Nacional se constata la curiosidad que se tenía por las vestimentas orientales. Al referirse a las pinturas tártaras y a los papeles pintados que se importaban en los barcos se afirmaba que «pueden ser muy excelentes y estrañas por retratar los trages tartaros»o los «vestuarios de los chinos». ${ }^{100}$ Este interés por las escenas cotidianas en

96 Registro del Buen Consejo, Cádiz, 15 de julio de 1767, AGI, Contratación, 2436, N.1, 17r-18r. Registro de la Santa Rosa de Lima, Cádiz, 11 de agosto de 1770, AGI, Contratación, 2436, N.2, R.1, 7v-10v.

97 Registro de la Venus, Cádiz, 21 de julio de 1773, AGI, Contratación, 2437, N.2, 221v-222r.

98 Registro de la Palas, Cádiz, 17 de julio de 1772, AGI, Contratación, 2436, N.3, 705v-706r.

99 Registro de la Venus, Cádiz, 21 de julio de 1773, AGI, Contratación, 2437, N.2, 298r.

100 Géneros y metales de China de nombres no comunes que conducen el navío Buen Consejo y las fragatas Venus y Santa Rosa, 1770, AHN, Diversos-Colecciones, 30, N.6. 
China se puede relacionar con el éxito de los biombos de Coromandel con representaciones de ambientes palaciegos, o con la porcelana de la Compañía de las Indias en la que aparecían mandarines con trajes suntuosos y de colores vivos. De una manera más general, este gusto se integra también perfectamente en la moda europea de la chinoiserie y su fascinación por el «exotismo» oriental.

En la fragata Palas iría el mayor volumen de cajones que dirigiría Simón de Anda a su familiar, trece. En el número 1 iba un baúl de maque negro de China con telas y porcelana, en el número 2 otro baúl de maque negro con 100 libras de canela china, en los cajones del 3 al 6, una vajilla de loza fina de China de quinientas piezas, en el 7 una mesa de palo de rosa de China, en la 8 siete figuras de barro de China, en el 9 dos biombos, mientras que en el 10 y en el 11 encontramos dos tanques para pescado de loza fina de China y un juego de café compuesto por 48 piezas. ${ }^{101}$ De este conjunto de mercancías resultan especialmente interesantes los «veinte cueros maqueados y pintados en ellos la historia de Don Quijote de la Mancha», que componían dos biombos. Se trata de un ejemplo del impacto de la mundialización en la cultura material y el arte de la época, ya que encontramos un mueble típicamente asiático que fue realizado por artesanos locales a partir de grabados europeos. El tema del Quijote debió de gozar de cierto éxito entre los encargos ya que seis años después el comerciante Francisco Gómez Enríquez aprovecharía la generala de 300 pesos que comprase a Juan Naranjo para transportar: «treinta y cuatro cuadros dorados con vidrios de la Historia de Don Quijote» a dos pesos cada uno. ${ }^{102}$

La siguiente remesa de Simón de Anda viajó en la fragata Juno, que en 1775 condujo ocho cajones para su hijo. Aquí vuelven a aparecer cajas de maque, abanicos de nácar, carey, marfil o caña, objetos de filigrana, porcelanas, etc. Además se incluyen muebles de lujo como un baúl de palo de rosa y otro de marfil con cerraduras de plata; dos rosarios de oro y perlas; dos petates de marfil valorados en 100 pesos; y valiosas objetos litúrgicos: una Virgen del Carmen y un San Gerónimo de colmillo de caimán con guarniciones de oro. ${ }^{103}$ La fragata Astrea (1776) sería la última en la que el gobernador manifestaría mercancías, siendo lo más destacable ocho cajuelas de carey, un tocador con marco y remate de plata de filigrana, y una

101 Registro de la Palas, Cádiz, 16 de julio de 1774, AGI, Contratación, 2437, N.3, 403r y v.

102 Registro de la Juno, Cádiz, 15 de julio de 1780, AGI, Contratación, 2438, N.3, 324r-324v.

103 Registro de la Juno, Cádiz, 17 de julio de 1775, AGI, Contratación, 2437, N.4, 475r-479v. 
papelera de ébano con herrajes también de filigrana. ${ }^{104}$ Después de la muerte de Simón de Anda, su sobrino, Juan Francisco de Anda, continuaría con los envíos a su primo Tomás de Anda. En este caso, entre los objetos de lujo remitidos se encontraban algunos que debieron pertenecer al gobernador y, por lo tanto, también tendrían un valor sentimental. Especial interés debieron tener «quatro sellos con el escudo de armas del Ylm. Señor don Simón de Anda y Salazar», uno de oro, dos de plata y uno de cobre, y «una medalla de cobre también con dichas armas». ${ }^{105}$

El volumen de las cargas que el gobernador despachó para España nos lleva a plantearnos dos cuestiones. La primera es cómo el cargo que ostentaba en Filipinas y la facilidad con la que podía acceder a mercancías asiáticas a precios económicos, hicieron que este consiguiese numerosos objetos de alto valor. La segunda tiene que ver con el elevado número de géneros enviados, que nos lleva a preguntarnos si una parte no estaría destinada a la venta en su destino. En este caso, los regalos serían una forma encubierta de participar en el comercio de mercancías asiáticas con mayores márgenes de beneficio, ya que solo se pagaba un dos y medio por ciento de impuestos a su salida frente al resto de géneros, que pagaban en Manila y Cádiz.

Este pudo ser el caso del regalo que encaminó Manuel Fernández Toribio, castellano del castillo de Santiago en la ciudad de Manila, a su hijo Francisco Javier, residente en Sevilla. Junto a piezas más singulares que podrían ser del agrado del receptor, cómo unas imágenes de San José y del niño Jesús de marfil o un quitasol de seda de Cantón, iban «498 peines de carey corbos con flores sobre doradas de canto muy fino» $\mathrm{y}$ «260 peines de marfil». ${ }^{106}$ Nuevamente, es difícil pensar que un número tan grande de estos objetos no fuese comercializado. También cabe la posibilidad de que algunos objetos específicos fueran reutilizadas posteriormente como presentes a personajes cercanos a la familia. El uso que se hacía de estos regalos resulta también sospechoso en el caso de implicar a mercaderes, ya que podrían intentar presentar las mercancías de esta manera para pagar menos impuestos. Laureano de Meneses, vecino y del comercio de Manila, envió dos cajoncitos de presente a un tío residente en Madrid,

\footnotetext{
104 Registro de la Astrea, Cádiz, 20 de julio de 1776, AGI, Contratación, 2437, N.5, R.2, $744 \mathrm{v}-745 \mathrm{v}$.

105 Registro de la Juno, Cádiz, 27 de julio de 1777, AGI, Contratación, 2438, N.1, 16v-17v.

106 Registro de la Palas, Cádiz, 17 de julio de 1772, AGI, Contratación, 2436, N.3, 702v-703r. Un año después Francisco Javier Fernández Toribio viajaría a Manila con su familia y parte de sus propiedades. Licencias de pasajeros, criados, libros y armas a Fernández, Madrid, 21 de diciembre de 1773, AGI, Filipinas, 344, L.13, 91r-91v.
} 
consignándolos a José Savater y compañía. Dentro iban un juego de té y otro de café de loza de China. ${ }^{107}$

Otro funcionario que remitiría enormes cantidades de objetos a un familiar en la Península sería Francisco Leandro de Viana, quien haría llegar el «ajuar y servicio» de su casa a José Francisco de Viana, canónigo de la iglesia de Palencia. Entre los objetos consignados destacaban dos canapés, cuatro mesas, y dieciséis pantallas de charol, «cinco flores de piedra blanca de China con sus peanas de piedra negra», cuarenta y una «repisas pequeñas con sus marquitos y láminas de nácar y marfil», «quince láminas pequeñas o quadros de pintura de China sobre vidrio», y porcelana. ${ }^{108} \mathrm{Si}$ lo que Viana pretendía era ofrecer estos objetos a su familiar, el gesto podría verse deslucido por encontrarse usados y maltratados varios de los muebles.

\section{Conclusiones}

Los estudios realizados sobre el interior de las bodegas de los barcos de la Armada que entre 1765 y 1784 unieron Cádiz y Manila a través del cabo de Buena Esperanza son todavía escasos. La reivindicación de su importancia política, económica y científica debe completarse con análisis más pormenorizados de las mercancías que se transportaron y de las redes que se tejieron en torno a las mismas.

La mayoría de las mercancías de los barcos era destinada al comercio pero también hubo espacio para un pequeño grupo de regalos. Estos presentes fueron de varios tipos, desde objetos curiosos o de historia natural hasta piezas con un elevado valor social y económico. A lo largo del trabajo fueron organizados en función de las motivaciones que animaron a sus emisores, variando entre aquellas de naturaleza política (destinadas al rey o a alguno de sus funcionarios), económica (entre particulares), simbólica y religiosa, o afectiva (familiares).

Los regalos que se remitieron a la corte fueron analizados desde dos puntos de vista. En primer lugar, se integraron en un contexto de cambios culturales, en los que a la vieja costumbre de dirigir objetos excepcionales al rey se sumaron los nuevos intereses científicos de la ilustración por conocer y clasificar la realidad física. Así, las dádivas podían responder a una iniciativa particular y acabar en las colecciones particulares de la familia real,

107 Registro de la Juno, Cádiz, 15 de julio de 1780, AGI, Contratación, 2438, N.3, 213r.

108 Registro del Buen Consejo, 15 de julio de 1767, AGI, Contratación, 2436, N.1, 21r-26r. 
o ser fruto de un plan organizado por instrucciones reales que pretendía proporcionar material a las nuevas instituciones científicas creadas por los Borbones. En segundo lugar, los regalos fueron pensados dentro de la cultura política del Antiguo Régimen, como un mérito que debía ser correspondido por el monarca o alguno de sus ministros. En este sentido, dado que el don influía en sus decisiones, pudo considerarse un tipo de corrupción del sistema, ya que anteponían los intereses personales a los del reino. Este tipo de prácticas era aceptado con normalidad, como demuestra su manifestación y registro en las cargas de los barcos, y sugiere que en el siglo XVIII aun no se había consolidado el proceso de separación entre lo público y lo privado, manteniendo prácticas habituales del periodo de los Austrias.

El regalo no sería una práctica aislada e individual sino que formaría parte de una dinámica de formación de redes sociales informales que contribuían al funcionamiento del sistema económico. Una nueva ruta necesitaba tejer nuevas relaciones que le ayudaran a consolidarse. Los presentes estudiados explican cómo se llevó a cabo este proceso, ya que en algunos casos dejaron un rastro que permite revelar relaciones personales o económicas solo intuidas hasta el momento. Así, las redes que desvelan estos objetos muestran hasta qué punto comerciantes y funcionarios mantenían negocios juntos.

Si lo que se pretendía era agradar o ganar el favor de un individuo, los objetos asiáticos eran una herramienta especialmente apropiada, ya que estaban envueltos en un halo de riqueza y sofisticación. Al mismo tiempo, las dádivas a familiares y las limosnas a instituciones religiosas revelan una dimensión no material de esta práctica. Por medio de donaciones se aumentaba el capital social y simbólico del linaje en sus lugares de origen y, en el caso de los comerciantes con pretensiones nobiliarias, ayudaba a imitar una de las prácticas habituales de la aristocracia española.

A partir de las fuentes es difícil saber si todos los regalos se debieron a la iniciativa del remitente o si alguno de ellos respondió a un encargo previamente acordado. Tanto los vecinos de Filipinas como aquellos que estaban de paso tenían la posibilidad de acceder directamente a los mercados asiáticos. Esta circunstancia no solo les facultaba para obtener las mercancías a mejores precios sino también para encargarlas a los artesanos según sus intereses. De esta forma, muchas piezas fueron individualizadas al colocarles, por ejemplo, el escudo de armas del beneficiario.

Finalmente, los regalos podían despacharse de manera independiente o ir dentro de los equipajes. Su movimiento desde Asia hasta Europa 
contribuyó al desarrollo de una cultura material que, por el origen de sus piezas, puede definirse como mundial. Al mismo tiempo, estos objetos se integraron en un contexto de «orientalismo» en la sociedad española que, a pesar de ser notable desde el siglo XVI, tomaría un nuevo impulso con la moda de la chinoiserie difundida desde Francia.

Recibido el 17 de marzo de 2016 Segunda versión el 5 de junio de 2016

Aceptado el 14 de junio de 2016

\section{Referencias bibliográficas}

Aguado de los Reyes, Jesús, Riqueza y sociedad en la Sevilla del siglo XVII, Sevilla, Fundación Fondo de Cultura de Sevilla, Universidad de Sevilla, 1994.

Anes Fernández, Lidia, «Comercio con América y títulos de nobleza: Cádiz en el siglo XVIII», Cuaderno Dieciochesco, 2, Alicante, 2001, 109-149.

Bernabéu Albert, Salvador, El Pacífico ilustrado, Madrid, Mapfre, 1992.

Bernabéu Albert, Salvador, «Ciencia ilustrada y nuevas rutas: las expediciones de Juan de Lángara al Pacífico, 1765-1773», Revista de Indias, 47, Madrid, 1997, 447-467.

Bernabéu Albert, Salvador, La aventura de lo imposible. Expediciones marítimas españolas, Madrid-Barcelona, Lunwerg editores, 2000.

Cañeque, Alejandro, «De parientes, criados y gracias. Cultura del don y poder en el México colonial (siglos XVI-XVII)», Histórica, 29, 1, México, 2005, 7-42.

Cosano Moyano, José, «El comercio directo Cádiz-Manila en navíos de la Real Armada (1765-1784)», Boletín de la Real Academia de Córdoba, 102, Córdoba, 1981, 183-220.

Cosano Moyano, José, «Hombres, mercancías y precios en el tráfico comercial directo entre España y Filipinas en la segunda mitad del siglo XVIII», Actas II Coloquio de Historia de Andalucía, Córdoba, 1983, I, 553-569.

De Mello Pereira, Magnus Roberto, «"Las cosas singulares de piedras, animales, plantas": La formación y el funcionamiento de la red imperial española de remesas científicas en el Virreinato del Río de la Plata», Anais do Museu Paulista, 21, 1, São Paulo, 2013, 91-138.

De Vos, Paula, «Natural History and the Pursuit of Empire in Eighteenth-Century Spain», Eighteenth-Century Studies, 40, 2, New York, 2007, 209-239.

Díaz-Trechuelo, María Lourdes, La Real Compañía de Filipinas, Sevilla, Escuela de Estudios Hispano-Americanos, 1965.

Díaz-Trechuelo, María Lourdes, Filipinas. La gran desconocida (1565-1898), Pamplona, EUNSA, 2001. 
Escoto, Salvador P., «Francisco Xavier Salgado, Civil Servant and Pioneer Industrialist in Eighteeenth Century Philippines», Southeast Asian Studies, 36, 3, Kioto, 1998, 273-292.

Figueroa, Marcelo, «Cuestionarios, instrucciones y circulación de objetos naturales entre España y América (siglos XVI y XVIII)», Anuario del Centro de Estudios Históricos «Prof. Carlos S. A. Segreti», 12, Córdoba (Argentina), 2012, 121-136.

García-Abásolo, Antonio, «Ensayando una doble vía. La ruta Cádiz-Manila», en El Galeón de Manila, Madrid, Ministerio de Educación, 2000, 215-226.

Gil, Juan, La India y el Lejano Oriente en la Sevilla del siglo de oro, Sevilla, Ayuntamiento de Sevilla, Biblioteca de Temas Sevillanos, 2011.

Goikoetxea Marcaida, Ángel, La botánica y los naturalistas en la Ilustración vasca, Real Sociedad Bascongada de Amigos del País, 1990.

Gómez Centurión, Carlos, «Curiosidades vivas. Los animales de América y Filipinas en la Ménagerie real durante el siglo XVIII», Anuario de Estudios Americanos, 66, 2, Sevilla, 2009, 181-211.

Gómez Centurión, Carlos, Alhajas para soberanos. Los animales reales en el siglo XVIII: de las leoneras a las mascotas de cámara, Valladolid, Junta de Castilla y León, 2011.

Heredia Moreno, Carmen, «Arte Hispanoamericano en Navarra», Cuadernos de la Cátedra de Patrimonio y Arte Navarro, 3, Pamplona, 2008, 341-376.

Herrero Gil, María Dolores, «El "Punto de Vista" o la revisión de dos viajes a Extremo Oriente: El Hércules, de la compañía gaditana "Ustáriz y San Ginés"», Revista Española del Pacífico, 21-22, Madrid, 2008-2009, 89-132.

Hespanha, Antonio M., La Gracia del Derecho: Economía de la Cultura en la Edad Moderna, Madrid, Centro de Estudios Constitucionales, 1993.

Lomnitz, Claudio (org.), Vicios públicos, virtudes privadas: la corrupción en México, México, CIESAS, Miguel Angel Porrúa, 2000.

Malo de Luque, Eduardo, Historia política de los establecimientos ultramarinos de las naciones europeas, Madrid, Imp. Antonio de Sancha, 1790, tomo V.

Martínez del Cerro, Victoria E., Una comunidad de comerciantes: navarros y vascos en Cádiz, segunda mitad del siglo XVIII, Sevilla, CES de Andalucía, 2006.

Martínez Shaw, Carlos, El sistema comercial español del Pacífico: (1765-1820), Madrid, Real Academia de la Historia, 2007.

Martínez Shaw, Carlos y Alfonso Mola, Marina, «España y el comercio de Asia en el siglo XVIII: Comercio directo frente a comercio transpacífico», en Lobato, Isabel y Oliva, José M. (eds.), El sistema comercial español en la economía mundial, siglos XVII-XVIII, Huelva, Universidad de Huelva, 2013a, 325-380.

Martínez Shaw, Carlos y Alfonso Mola, Marina, «La Armada en el cabo de Buena Esperanza. La primera expedición del navío Buen Consejo, 1765-1767», Anuario de Estudios Atlánticos, 59, Gran Canaria, 2013b, 431-477. 
Mauss, Marcel, Ensayo sobre el don: forma y función del intercambio en las sociedades arcaicas, Buenos Aires, Katz Editores, 2009.

Mazo, Ana Victoria, Los cuatro elefantes del rey Carlos III, Madrid, Museo Nacional de Ciencias Naturales, CSIC, 2008.

Montes González, Francisco, «En torno a la imagen del virrey como mecenas de las Artes en la Nueva España», en González Gómez, J. M. y Mejías Álvarez, M. J. (coords.), Estudios de historia del arte: centenario del Laboratorio de Arte (1907-2007), Sevilla, Universidad de Sevilla, 2009, vol. 1, 499-512.

Pietschmann, Horst, El estado y su evolución al principio de la colonización española de América, México, Fondo de Cultura Económica, 1989, 163-183.

Pietschmann, Horst, «Corrupción en las Indias Españolas: Revisión de un debate en la historiografía sobre Hispanoamérica colonial», en González Jiménez, Manuel et al., Instituciones y corrupción en la historia, Valladolid, Universidad de Valladolid, 1998, 31-52.

Rivas Álvarez, José Antonio, Miedo y piedad: los testamentos sevillanos del siglo XVIII, Cádiz, Diputación de Cádiz, 1986.

Sánchez Espinosa, Gabriel, «Un episodio en la recepción cultural dieciochesca de lo exótico: la llegada del elefante a Madrid en 1773», Goya: Revista de Arte, 295-296, Madrid, 2003, 269-286.

Sanz, María Jesús y Dabrio, M. ${ }^{a}$ Teresa, «Inventarios artísticos sevillanos del s. XVIII. Relación de obras artísticas», Archivo Hispalense, LVII, Sevilla, 1974, 89-150.

Torales Pacheco, M. ${ }^{a}$ Cristina, Ilustrados en la Nueva España: los socios de la Real Sociedad Bascongada de Amigos del País, México, Univ. Iberoamericana, 2001.

Van Klaveren, Jacob, «The Concept of Corruption», en Heideheimer, A.J.; Johnston, M. y Levine, V. (eds.), Political Corruption: a Handbook, New Brunswick, Transaction, 1990, 25-28.

Vicens Vives, Jaime, «Estructura administrativa estatal en los siglos XVI y XVII», en Izquierdo Martín, Jesús y Sánchez León, Pablo (coords.), Clásicos de historia social de España: una selección crítica, Madrid, UNED, 2000, 117-152.

Yuste, Carmen, Emporios transpacíficos. Comerciantes mexicanos en Manila, 1710-1815, México, Instituto de Investigaciones Históricas, UNAM, 2007. 